\title{
RECOVERY OF BY-PRODUCTS FROM THE OLIVE OIL PRODUCTION AND THE VEGETABLE OIL REFINING FOR BIODIESEL PRODUCTION
}

\author{
Mariana Cruz ${ }^{1}$, Emanuel Costa ${ }^{1}$, Manuel Fonseca Almeida ${ }^{1}$, Maria da Conceição \\ Alvim-Ferraz ${ }^{2}$ and Joana Maia Dias ${ }^{1, *}$ \\ ${ }^{1}$ LEPABE, Departamento de Engenharia Metalúrgica e de Materiais, Faculdade de Engenharia, Universidade do Porto, R. Dr. \\ Roberto Frias, 4200-465 Porto, Portugal \\ ${ }^{2}$ LEPABE, Departamento de Engenharia Química, Faculdade de Engenharia, Universidade do Porto, R. Dr. Roberto Frias, \\ 4200-465 Porto, Portugal
}

Article Info:
Received:
26 June 2018
Revised:
1 October 2018
Accepted:
4 November 2018
Available online:
14 November 2018
Keywords:
Acid oil
Soapstock
Olive pomace oil
Enzymatic hydroesterification
Transesterification

Article Info:

Revised:

Accepted:

Keywords:

Soapstock

Enzymatic hydroesterification

Transesterification

\begin{abstract}
The by-products acid oil from soapstock of vegetable oil refining and olive pomace oil were evaluated for biodiesel production. Enzymatic hydroesterification was studied to convert the acid oil ( $34 \mathrm{wt}$ \% free fatty acids) into methyl esters; due to the low free fatty acid content of the fresh olive pomace oil ( $2 \mathrm{wt} . \%)$, alkaline transesterification was conducted. The results from the enzymatic hydrolysis $\left(35^{\circ} \mathrm{C}, 24 \mathrm{~h}, 200 \mathrm{rpm}\right)$ showed a clear influence of enzyme concentration ( $0.1-5 \mathrm{wt} . \%$, relative to oil) and water:oil ratio (1:0.25 and 1:0.5 w:w) towards free fatty acid production. After applying the best established conditions ( 3 wt.\% of enzyme and 1:0.5 water: oil ratio, w:w), enzymatic esterification was performed $\left(35^{\circ} \mathrm{C}, 7 \mathrm{~h}, 200 \mathrm{rpm}, 2 \mathrm{wt} . \%\right.$ of enzyme and 2:1 molar ratio of methanol to acid). Hydroesterification led to a product with a methyl esters content of about $84 \mathrm{wt} . \%$ whereas the esterification alone allowed reaching only around $65 \mathrm{wt} . \%$. The olive pomace oil was obtained from chemical extraction of fresh olive pomace ( $18 \mathrm{wt}$ \% of oil). By performing direct alkaline transesterification $\left(65^{\circ} \mathrm{C}, 1 \mathrm{wt} . \% \mathrm{NaOH}, 1 \mathrm{~h}\right.$ and $6: 1$ molar ratio of methanol to oil) a product with a purity of 90 wt.\% was obtained. The olive pomace storage in the air during 2 weeks led to an increase in the oil free fatty acid content of almost 2 fold showing the relevance of developing storage and conservation strategies to ensure a sustainable recovery of this by-product. Both by-products showed potential for biodiesel production.
\end{abstract}

\section{INTRODUCTION}

Biodiesel is considered a very promising biofuel for fossil fuels replacement and might have an important role to reduce the global energy demand due to its environment-friendly and renewable properties (Mahmudul et al., 2017).

There are several methods for biodiesel production such as blending, microemulsification, pyrolysis and transesterification, using edible and non edible oils as well as waste raw materials. Alkaline transesterification is one of the most common and attractive processes to produce biodiesel, being widely accepted (Baskar and Aiswarya, 2016; Verdugo et al., 2011). Despite the difficulties during purification, associated with loss of product yield and management of wastewaters (Machado et al., 2016), it is still the most employed route for economic reasons. However, the homogeneous alkaline catalysed process cannot be applied to a material with a high free fatty acid (FFA) content due to soap formation; the conventional reported limit is $1 \mathrm{wt}$.\% FFA content, corresponding roughly to $2 \mathrm{mg}$ $\mathrm{KOH} \mathrm{g}^{-1}$ in terms of acid value (Dias et al., 2009). The pretreatment of raw materials with the objective of decrease the FFA content can be achieved by performing different types of reactions, namely homogeneous acid esterification, enzymatic hydroesterification and glycerolysis, which recover the acids present (Živković et al., 2017).

The hydroesterification represents a new alternative for the production of esters, since it allows the use of raw materials with high water and FFA contents. The FFA produced by hydrolysis can be further esterified by a short chain alcohol, producing esters and water. Firstly, glycerides are hydrolysed to FFA and then esterified into esters using methanol or ethanol and different catalysts (Zenevicz et al., 2016). Recently, the use of enzymes as an effective biocatalyst has been an emerging contribution for 
biodiesel production, since they have tolerance to FFA and water, require mild temperatures for the reaction and show versatility to catalyze hydrolysis, esterification and transesterification, thus enabling hydroesterification (Avhad and Marchetti, 2015).

Most of the biodiesel production costs (around 80\%) are related to the raw material, so exploring low-cost raw materials for this process is still of high relevance (Knothe and Razon, 2017). Non-edible oils can be seen as the future sources of biodiesel, since they do not compete with food supply; however, they have as disadvantage the need of soil support for its growth.

By-products such as soapstocks are seen as potential low cost feedstocks for biodiesel production (Piloto-Rodríguez et al., 2014). The soapstock, which results from the neutralization of the raw vegetable oils, is normally acidified with a strong mineral acid, which allows the release of FFA. The process generates a fraction which is generally dark in colour, known as acid oil, that usually contains water (0.8-3.1\%), FFA (39-79\%), acylglycerols (18-30\%) and unsaponifiable matter (0.4-4.2\%) (Echim et al., 2009). Soapstock is generated at a rate of about $6 \%$ Vol. of refined oil (Park et al., 2008). Another by-product from vegetable oil refining, the fatty acid distillate or deodorizer distillate, is obtained in the final deodorization stage and can also contain high amounts of FFA (Piloto-Rodríguez et al., 2014).

In the Mediterranean region there is a large production of olive oil for human consumption and a by-product of this industry is formed, the olive-pomace, which might still present a relevant oil content (on average 5-8\%, wet basis) (Göğüş and Maskan, 2006). In Portugal, the olive production forecast for 2016 was around 476003 t (INE, 2018). For the traditional olive press process, Azbar et al. (2004) indicates that in the olive oil production, $1 \mathrm{t}$ of olives leads to around $400 \mathrm{~kg}$ of solid waste (olive pomace), 200 $\mathrm{kg}$ of olive oil and $600 \mathrm{~kg}$ of wastewater containing residual solids and oil. It is therefore advisable to develop studies regarding the recovery of such material, in particular, for biofuels production.

The present work evaluated the use of two by-products for biodiesel production (acid oil from soapstock from vegetable oil refining and olive pomace oil). Taking into account the FFA content associated with each raw material, for biodiesel production the enzymatic hydroesterification was evaluated from the acid oil from soapstock and the alkaline transesterification was performed directly to the olive pomace oil and to the best product of the hydroesterification aiming maximum biodiesel purity.

\section{MATERIALS AND METHODS}

\subsection{Materials}

The acid oil from soapstock of vegetable oil refining (mixture of sunflower and soybean seeds) was provided by the company Nature Light, S.A. Olive pomace was supplied from an olive oil company of Northern Portugal (DouroSol Company). Petroleum ether (LabChem $\geq 90 \%$ ) was used for chemical oil extraction (soxhlet).

Methanol (Fischer Scientific $\geq 99 \%$ ) was used as the acyl acceptor. The catalysts used were sodium hydrox- ide powder $97 \%$ (reagent grade, Aldrich) and the lipase from Thermomyces lanuginosus (Lipolase 100L, activity $\geq$ $100,000 \mathrm{U} / \mathrm{g}$ ) purchased from Sigma-Aldrich. All the other reagents were of analytical grade.

\subsection{Extraction of olive pomace oil}

The oil extraction was performed using a Soxhlet extractor $(1 \mathrm{~L})$. Firstly, the raw material was crushed in a mortar and placed inside the thimble. Then, the thimble was dipped in petroleum ether solvent for $6 \mathrm{~h}$ (equivalent to 14 turns of the solvent in the extractor). After the extraction, the solvent was removed in a rotary evaporator at close to $70^{\circ} \mathrm{C}$. Several extraction cycles were conducted until reaching the necessary amount of oil for the study. The procedure performed was based in NP EN ISO 659 (2002).

In order to evaluate the effect of the storage in the FFA content of the oil, the extraction was carried out with the fresh olive pomace and after two weeks of storage at the air (room temperature).

\subsection{Analytical procedures}

The physicochemical properties determined in the acid oil from soapstock were the FFA content and the water content. The FFA content was determined according to NP EN ISO 660 (tritimetric method) and the results are expressed as the weight percentage in terms of oleic acid equivalents (molar mass of $282 \mathrm{~g} \mathrm{~mol}^{-1}$ ).

Taking into account the expected values for water content, it was determined by weight loss at $\mathrm{T}=105^{\circ} \mathrm{C} \pm$ $2^{\circ} \mathrm{C}$ (oven method), until constant weight, according to EN 12880 (2000) for both by-products; results are expressed as weight percentage, in wet basis.

For the olive pomace, the oil content was determined according to NP EN ISO 659. Oxidation stability and FFA content were determined in the extracted olive pomace oil. The oxidation stability was measured in agreement with the EN 14112 by accelerated oxidation using a Rancimat equipment (Metrohm).

The methyl ester content of the final products was determined according to EN 14103 (2003) by gas chromatography, using a Dani Master GC with a DN-WAX capillary column of $30 \mathrm{~m}, 0.25 \mathrm{~mm}$ internal diameter and $0.25 \mu \mathrm{m}$ of film thickness. The temperature program used was as follows: $120^{\circ} \mathrm{C}$ was initially selected as the starting temperature, followed by a temperature rise at $4^{\circ} \mathrm{C}$ per minute, up to $220^{\circ} \mathrm{C}$, holding time of 10 minutes.

\subsection{Recovery of acid oil from soapstock}

\subsubsection{Enzymatic hydroesterification}

The hydroesterification process occurs in two-steps. Firstly, the glycerides are hydrolysed to FFA and glycerol and after, the FFA are esterified using an alcohol to produce biodiesel (esters) and water. The hydrolysis reactions were carried out in $100 \mathrm{~mL}$ Erlenmeyer flasks in an orbital shaking incubator (Agitorb 200IC), with constant stirring of 200 rpm, during $24 \mathrm{~h}$ at $35^{\circ} \mathrm{C}$ according to the literature (Aguieiras et al., 2014; Cavalcanti-Oliveira et al., 2011; Kabbashi et al., 2015; Watanabe et al., 2007).

For the hydrolysis reaction, $25.0 \mathrm{~g}$ of the acid oil were 
used and the defined amount of water was added (mass ratio of oil:water $1: 0.25$ or 1:0.5). After reaching the reaction temperature, the established amount of enzyme (0.2, 1,3 and 5 wt.\%) was also added to the reactional mixture.

The hydrolysis reaction generates two phases: oil and water/glycerol that are essentially immiscible at mild temperatures, and can be separated by centrifugation (Machado et al., 2016; Vescovi et al., 2016). Thus, at the end of the reaction, the final product was centrifuged (Hermile Z200A) at $3500 \mathrm{rpm}$ during 12 minutes and two distinct phases were formed and separated. The final FFA content of the oily phase was determined.

Esterification reactions were carried out under batch conditions using $100 \mathrm{~mL}$ Erlenmeyer flasks in an orbital shaking incubator (Agitorb 200IC). The present study was performed using the best conditions $\left(35^{\circ} \mathrm{C}, 200\right.$ r.p.m, molar ratio of acid:methanol 1:2 and 2 wt.\% of enzyme) by adjusting, in preliminary studies, those obtained from a previous study (Cruz et al., 2017).

The enzymatic esterification was carried with the best result in terms of FFA production obtained by the hydrolysis reaction, monitored for $7 \mathrm{~h}$, based on the literature (Cruz et al., 2017) and compared with the enzymatic esterification of untreated oil, under the same conditions. Samples of around $0.4 \mathrm{~mL}$ were collected at different time intervals to measure the FFA content. All experiments were performed in duplicate and the variation was evaluated in terms of the relative percentage difference to the mean (RPD). In all cases, RPD was less than $10 \%$.

\subsection{Transesterification}

Synthesis of the final biodiesel product by alkaline transesterification was conducted with the product from the hydroesterification obtained under the best established conditions. In the case of olive pomace oil, the transesterification was performed directly.

The alkaline transesterification was performed in a batch reactor at $65^{\circ} \mathrm{C}$ during $1 \mathrm{~h}$; the amount of catalyst was 1 wt. $\% \mathrm{NaOH}$ and the methanol:oil molar ratio was $6: 1$; purification was conducted by acid/water washing and drying procedures in agreement to previous studies (Dias et al., 2009).

\section{RESULTS AND DISCUSSION}

\subsection{Characterization of by-products}

\subsubsection{Acid oil from soapstock}

In spite of raw material being from the same source than that previously studied by Cruz et al. (2017), the FFA content was $34 \pm 1 \mathrm{wt}$. $\%$, possibly due to sampling in a different season of the year. This FFA content is quite low in comparison with values from the literature. Irandoust et al. (2012) reported $67.4 \%$ of FFA content for an acid oil from soapstock of soybean oil refining, whereas Chiplunkar and Pratap (2016) studied an acid oil from soapstock of sunflower oil refining with $65 \%$ of FFA content.

The oil water content was $4.8 \pm 0.1 \mathrm{wt} . \%$, in the range reported by Cruz et al. (2017). Pérez-Bonilla et al. (2011) reported a water content slightly lower (2.2 wt.\%) for an acid oil from soapstock of vegetable oil refining.

\subsubsection{Olive pomace oil}

Olive pomace oil is reported in the literature as having a high content of oil and water (Barbanera et al., 2016; Missaoui et al., 2017). In the present work, the following results were obtained: $18 \pm 2 \mathrm{wt}$.\% lipid content; moisture content of $26.8 \pm 0.2 \mathrm{wt} . \%$

The result of the lipid content shows the recovery potential of this by-product aiming biodiesel production. In terms of management and application, the high moisture content of olive pomace can affect the costs of transport and promote its degradation.

The FFA content determined in the olive pomace oil was 2.2 wt.\%. The value obtained was much lower than that reported by Che et al. (2012) which was around 22 wt.\%; Rajaeifar et al. (2016) studied an olive pomace oil with 5.75 wt.\% of FFA content. The low acid value obtained is attributed to the fact that it results from fresh olive pomace which was collected right after the mechanical extraction of olive oil.

Taking into account alkaline transesterification, the FFA content exceeds the reported limit of $1 \mathrm{wt} . \%$ (Dias et al., 2009). For this reason, pretreatments to decrease the FFA content might be required prior to the transesterification reaction. However, because of the low yields previously reported for two steps processes and the low FFA content obtained, the alkaline transesterification was still evaluated as a single process (Dias et al., 2009).

In order to evaluate the impact of storage, olive pomace oil was extracted after two weeks in the air at room temperature; the extracted oil presented around $4 \mathrm{wt} . \%$ of FFA content, corresponding to an increase in almost 2 fold of this parameter. It is therefore expected that the FFA content continues to increase with the time of the storage at the facilities where the olive oil is produced, until the end of the campaign. Such values will clearly impair the use of the conventional homogeneous alkaline transesterification process and therefore such conditions of storage should be revised aiming at recovering a high quality product from the olive pomace. Go et al. (2016) reported that FFA contents in agricultural biomass and residues increased significantly with increasing storage time. Treatments such as the storage below $0{ }^{\circ} \mathrm{C}$ or stabilization through drying or heating to remove moisture and deactivate the enzymes, are suggested to avoid FFA formation.

The oxidation stability of the oil was $12.7 \pm 0.5 \mathrm{~h}$, very high when compared with other raw materials used for biodiesel production like canola oil or soybean oil (Atabani et al., 2013) and should be related with its fatty acid profile and content in natural antioxidants (phenolic compounds) (Maurizio Servili and Montedoro, 2002). In fact, the low content in polyunsaturated fatty acids $(14.4 \% \mathrm{wt} . \%$, includes C18:2 and others presented in Table 1) is possibly one of the reasons for the high oxidation stability found for oil. The unsaponifiable matter might also be an indicator of the stability of this oil since bioactive compounds such as natural antioxidants found in this raw material are present in this fraction. In the present work it was not possible to perform this quantification; however, results of revised studies report that unsaponifiable matter represents around $2 \%$ 
TABLE 1: Fatty Acid Methyl Ester profile of biodiesel produced from olive pomace oil.

\begin{tabular}{c|c} 
Methyl ester of the following fatty acids & wt. \% \\
\hline C16:0 & 9.90 \\
\hline C18:0 & 3.20 \\
C18:1 & 71.3 \\
\hline C18:2 & 12.7 \\
\hline Others (<1 wt.\% each) & 2.90 \\
Mean molecular weight (g mol $\left.{ }^{-1}\right)^{\star}$ & 880 \\
\hline
\end{tabular}

${ }^{*}$ Calculated taking into account the profile

of the total weight (Bulotta et al., 2014; Chanioti and Tzia, 2017; Orozco et al., 2011).

\subsection{Enzymatic hydroesterification}

\subsubsection{Enzymatic hydrolysis}

As mentioned previously, enzymes are promising catalysts for biodiesel production by hydroesterification, since they work very well under mild conditions of temperature and pressure, and particularly, because lipases exhibit high activity for both hydrolysis and esterification reactions (Sousa et al., 2010).

The hydrolysis reaction was monitored by acid value determination during $24 \mathrm{~h}$ (Figure 1) and the effect of water:oil mass ratio (1:0.25 and 1:0.5 w:w) and enzyme concentration (0.2-5 wt.\%, relative to oil) were studied. The evolution with reaction time shows generally a gradual increase in FFA content, achieving a final FFA content of almost double of the initial in almost all conditions after $24 \mathrm{~h}$ (1440 min). It should be highlighted that the FFA content in the Figure 1 relates to the reaction mixture (there is a dilution effect) whereas the final FFA content was measured in the recovered oil after phase separation according to the methodology presented at the 2.3.1 section.

It is known that the water content affects the equi-

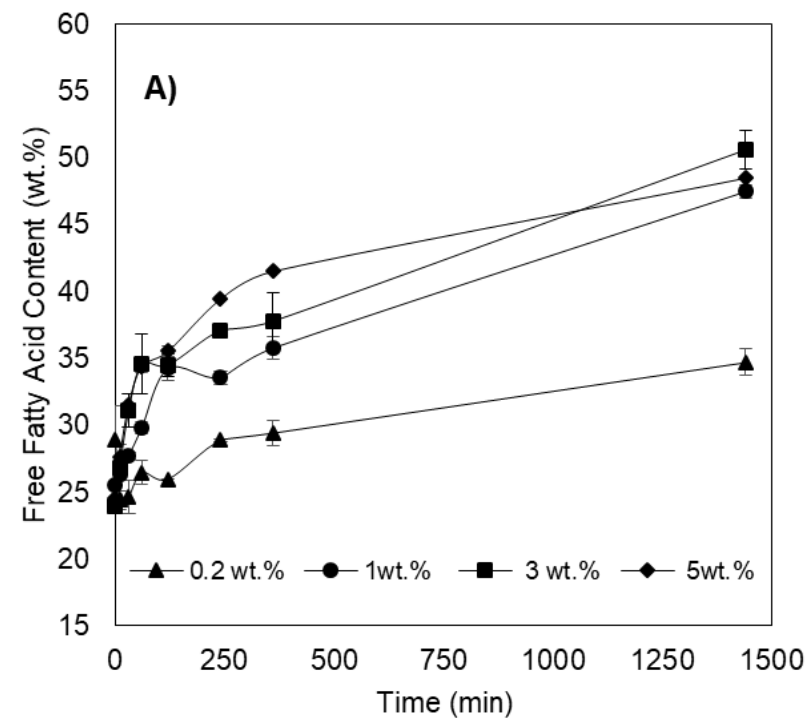

librium conversion of the reactions at the esterification/ hydrolysis and it can also affect the products distribution in the reaction medium (Foresti et al., 2007). After $24 \mathrm{~h}$, using 1:0.25 oil:water mass ratio, the final FFA content of the oil ranged from $58.1 \mathrm{wt} \%$ to $78.3 \mathrm{wt}$.\%, from the lowest to highest catalyst concentration of $0.2 \mathrm{wt} \%$ and $5 \mathrm{wt} . \%$ respectively. Using 1:0.5 oil:water mass ratio, the final FFA content of the oil ranged 47.9 wt.\% to 84.8 wt.\% from 0.2 wt.\% to $5 \mathrm{wt}$ \% , respectively.

At the lowest catalyst concentration (0.2 wt.\%) and water:oil mass ratio (1:0.25), the results are clearly different, with lower conversions, than at the other concentrations studied (1-5 wt.\%), as expected. The results for the 1:0.5 oil:water mass ratio using $0.2 \mathrm{wt}$.\% of catalyst seem interesting, although an increase in the reaction time more than 1440 minutes might be unfeasible towards industrial scale application.

The conversion increased with the increase of catalyst concentration, with the best results being obtained using higher water concentration. The highest FFA content was obtained using 5 wt.\% of enzyme and the highest oil:water ratio, which afforded a final FFA content of around 1.5 times the initial. Increasing the catalyst dose further resulted in a decrease in the FFA produced, though insignificantly (data not shown), a drawback which can be attributed to inability of the excess catalyst to reach the aqueous phase of the substrate (Kabbashi et al., 2015).

Aguieiras et al. (2014), by studying the hydrolysis of an acid oil (10.5 wt.\% FFA content) from macauba (Acrocomia aculeata), achieved $99.6 \%$ of FFA after $6 \mathrm{~h}$ at $30^{\circ} \mathrm{C}$. The reaction medium was composed of macauba acid oil and buffer $(50 \% \mathrm{v} / \mathrm{v})$, using a $0.1 \mathrm{~mol} \mathrm{~L}^{-1}$ sodium acetate buffer of $\mathrm{pH} 4.0$ and $2.5 \%(\mathrm{w} / \mathrm{v})$ of biocatalyst; Rodrigues and Ayub (2011) obtained a conversion of the FFA of about $95 \%$ after $10 \mathrm{~h}$ of enzymatic hydrolysis of refined soybean oil $\left(25.0\right.$ g, $30^{\circ} \mathrm{C}, 200$ r.p.m., 3:1 water:soybean oil molar ratio; 25 wt.\% enzyme (mixture of 65\% Thermomyces lanuginosus and 35\% Rhizomucor miehei); Vescovi et al., (2016)

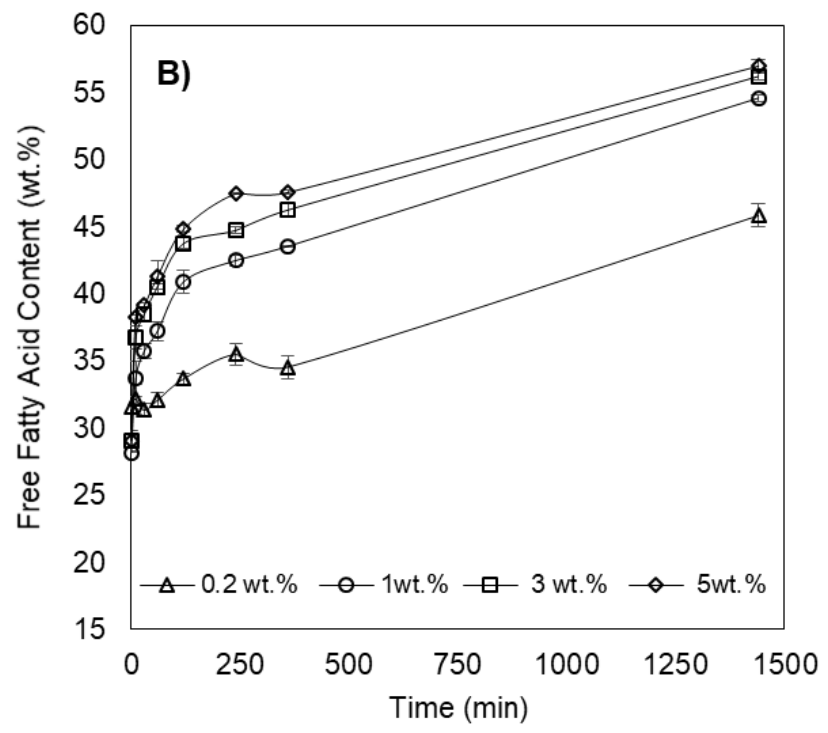

FIGURE 1: Release of fatty acids during hydrolysis of acid oil from soapstock using different concentrations of enzyme and two oil:water mass ratios. A) $1: 0.25$ and $\mathrm{B}) 1: 0.5$ (25 g of oil, $\left.35^{\circ} \mathrm{C}, 200 \mathrm{rpm}\right)$. 
achieved about $90 \%$ of conversion after $9 \mathrm{~h}$ of reaction using waste cooking oil (WCO) $\left(\sim 1.4 \mathrm{mg} \mathrm{KOH} \mathrm{g}^{-1}\right)$, reaching around $100 \%$ after $24 \mathrm{~h}$ and the hydrolysis reaction was carried out at $30^{\circ} \mathrm{C}$ in a salt-free aqueous medium (WCO/ water ratio of $1: 4, v / v)$ using lipase from Thermomyces lanuginosus (enzyme/WCO ratio of 1:5.6, w/w). The differences to the present study should be related with the different characteristics of the oils used and the variations of the conditions employed.

\subsubsection{Enzymatic esterification}

The esterification of hydrolysed acid oil was performed and compared with the esterification of acid oil without any pretreatment (Figure 2). Without the hydrolysis pretreatment the FFA content reduction was $53.4 \%$ and after hydroesterification the acid oil FFA content was reduced in $87.8 \%$.

Vescovi et al., (2016) using an hydrolysed waste cooking oil (acid value of $197.92 \mathrm{mg} \mathrm{KOH} \mathrm{g}^{-1}$ ) achieved around $90 \%$ of FFA content reduction at $6 \mathrm{~h}$ of enzymatic esterification, and there was not significant increase by increasing time up to $12 \mathrm{~h}$ of reaction (reaction conditions: $15 \mathrm{~g}, 40^{\circ} \mathrm{C}$; 10 wt.\% enzyme, acid:ethanol molar ratio of 1:7).

The methyl ester content was determined for the final products and the GC analysis showed about $65 \mathrm{wt} . \% \pm 1$ and 84 wt. $\% \pm 1$ of esters at the esterification and hydroesterification product, respectively. Since in the first case the initial FFA content was 34 wt.\% and in the second case was $81 \%$ (after hydrolysis), it was verified that not only FFA esterification but also the transesterification of mono-, di- and/ or triglycerides present occurred (Cruz et al., 2017). This, because taking into account the reaction stoichiometry, the mass of esters should not differ greatly from the mass of the acids. However, it would be extremely important for future work to analyse the mono-, di- and triglycerides profile of the acid oil and throughout the reactions (not possible under the present work), because it would lead to the clear understanding and consequently an accurate quantification of their role.

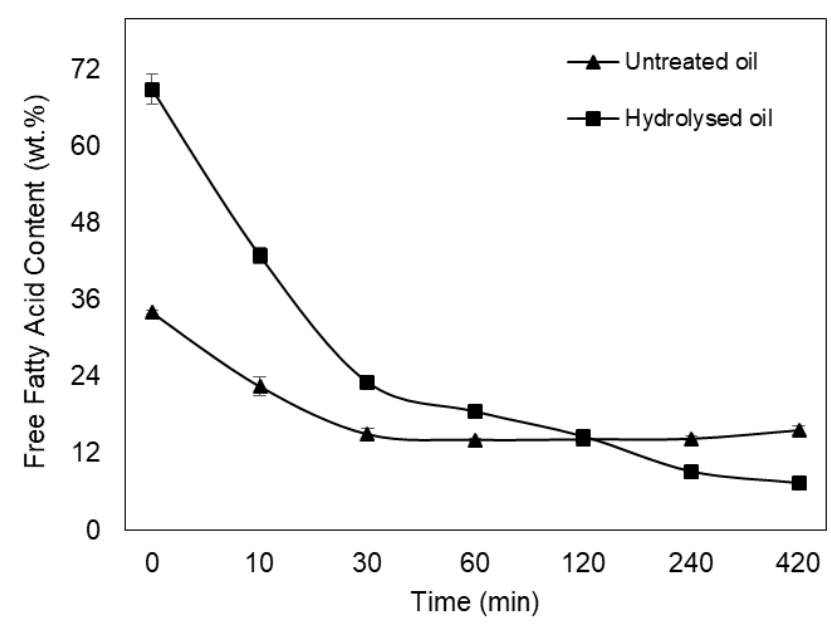

FIGURE 2: Reduction of free fatty acid content during enzyme catalysed esterification of untreated and hydrolysed acid oil (25 $\mathrm{g}$ of oil, $35^{\circ} \mathrm{C}, 200 \mathrm{rpm}$, molar ratio of FFA:methanol 1:2, 2 wt.\% enzyme).
The homogeneous alkaline transesterification was performed on the best pretreated product aiming to obtain a high purity (convert the remaining glycerides into methyl esters), in agreement with EN 14214 (> 96.5 wt.\% of methyl esters); however, biodiesel with around $90 \mathrm{wt} . \%$ of methyl ester content was obtained. Thus, it would not be advantageous its application (transesterification) under the conditions studied. The analysis of the methyl ester product showed predominance of C18:2 and C18:1 methyl esters (51 and $27 \mathrm{wt} \%$, respectively), similar to that reported Haas (2005) for an acid oil from soapstock of soybean oil (55 wt.\% and 17 wt.\% for linoleic and oleic acid, respectively).

\subsubsection{Alkaline transesterification of olive pomace oil}

Biodiesel production was performed using olive pomace oil without any pretreatment. The production of biodiesel directly from olive pomace oil was possible and led to a biodiesel with a purity close to $90 \%$, slightly lower than that required according to EN14214. López et al. (2014) obtained a biodiesel with 98 wt.\% methyl esters from direct transesterification of olive pomace oil (40 min, $60^{\circ} \mathrm{C}, 6: 1$ molar ratio of methanol:oil, $1.2 \mathrm{wt} . \%$ of $\left.\mathrm{KOH}\right)$. The oil presented however a very low FFA content $(0.3$ wt.\%).

The fatty acid profile for this oil is in agreement with that reported by Che et al. (2012) and Costa et al. (2013) for such oil type and shows the predominance of the oleic acid.

Taking into account the verified increase of the FFA content resulting from storage, the conventional alkaline transesterification should be inviable for such by-product. To avoid increased production costs, alternative storage conditions of olive pomace should be evaluated to ensure its higher quality.

\section{CONCLUSIONS}

The enzymatic hydroesterification of acid oil from soapstock presenting an FFA content of $34 \mathrm{wt} . \%$ led to a product with a final methyl esters content of about $84 \%$, a value higher than $65 \%$, obtained from the esterification alone. In agreement, such process seems to be promising towards the biocatalysed production of methyl esters from low cost raw materials.

The olive pomace oil obtained from fresh olive pomace showed recovery potential as raw material for biodiesel production. The original FFA content of about 2 wt.\% verified for this oil was low, but still higher than the threshold value of $1 \mathrm{wt} . \%$ generally agreeded for alkaline transesterification. In spite of that, the biodiesel produced directly from such oil without pretreatement led to a product with a methyl ester content of $90 \mathrm{wt} . \%$. Due to the fast increase of the oil FFA content resulting from the storage of the olive pomace during olive oil production campaigns, strorage conditions should be revised aiming to have a by-product with higher quality.

The studied by-products show potential as sustainable raw materials for biodiesel production. 


\section{AKNOWLEDGEMENTS}

This work was supported by projects (i) POCI-01-0145FEDER-006939 (Laboratório de Engenharia de Processos, Ambiente, Biotecnologia e Energia, UID/EQU/00511/2013) - funded by FEDER through COMPETE2020 - Programa Operacional Competitividade e Internacionalização ( $\mathrm{POCl})$ - and by national funds through FCT - Fundação para a Ciência e a Tecnologia and (ii) NORTE-01-0145-FEDER-000005 - LEPABE-2-ECO-INNOVATION, funded by FEDER - Fundo Europeu de Desenvolvimento Regional, through COMPETE2020 - Programa Operacional Competitividade e Internacionalização (POCI) and Programa Operacional Regional do Norte (NORTE2020). Emanuel Costa thanks FCT for the fellowship PD/BD/114312/2016.

\section{ABBREVIATIONS}

FFA: Free Fatty Acid(s)

RPD: Relative percentage difference to the mean

WCO: Waste cooking oil

\section{REFERENCES}

Aguieiras, E. C. G., Cavalcanti-Oliveira, E. D., de Castro, A. M., Langone, M. A. P., and Freire, D. M. G. (2014). Biodiesel production from Acrocomia aculeata acid oil by (enzyme/enzyme) hydroesterification process: Use of vegetable lipase and fermented solid as low-cost biocatalysts. Fuel, 135, 315-321. doi:https://doi.org/10.1016/j. fuel.2014.06.069

Atabani, A. E., Mahlia, T. M. I., Masjuki, H. H., Badruddin, I. A., Yussof, H. W., Chong, W. T., and Lee, K. T. (2013). A comparative evaluation of physical and chemical properties of biodiesel synthesized from edible and non-edible oils and study on the effect of biodiesel blending. Energy, 58, 296-304. doi:https://doi.org/10.1016/j.energy.2013.05.040

Avhad, M. R., and Marchetti, J. M. (2015). A review on recent advancement in catalytic materials for biodiesel production. Renew Sust Energ Rev, 50(Supplement C), 696-718. doi:https://doi. org/10.1016/j.rser.2015.05.038

Azbar, N., Bayram, A., Filibeli, A., Muezzinoglu, A., Sengul, F., and Ozer, A. (2004). A Review of Waste Management Options in Olive Oil Production. Crit Rev Env Sci TEc, 34(3), 209-247. doi:10.1080/10643380490279932

Barbanera, M., Lascaro, E., Stanzione, V., Esposito, A., Altieri, R., and Bufacchi, M. (2016). Characterization of pellets from mixing olive pomace and olive tree pruning. Renew Energ, 88, 185-191. doi:https://doi.org/10.1016/j.renene.2015.11.037

Baskar, G., and Aiswarya, R. (2016). Trends in catalytic production of biodiesel from various feedstocks. Renwe Sust Energ Rev, 57(Supplement C), 496-504. doi:https://doi.org/10.1016/j. rser.2015.12.101

Bulotta, S., Celano, M., Massimo Lepore, S., Montalcini, T., Pujia, A., and Russo, D. (2014). Beneficial effects of the olive oil phenolic components oleuropein and hydroxytyrosol: Focus on protection against cardiovascular and metabolic diseases. J Transl Med, 12, 219-228. doi: https://doi.org/10.1186/s12967-014-0219-9

Cavalcanti-Oliveira, E. D., Da Silva, P. R., Ramos, A. P., Aranda, D. A. G., and Freire, D. M. G. (2011). Study of soybean oil hydrolysis catalyzed by Thermomyces lanuginosus lipase and its application to biodiesel production via hydroesterification. Enzyme Res, 2011(1). doi:10.4061/2011/618692

Chanioti, S., and Tzia, C. (2017). Optimization of ultrasound-assisted extraction of oil from olive pomace using response surface technology: Oil recovery, unsaponifiable matter, total phenol content and antioxidant activity. LWT - Food Science and Technology, 79, 178-189. doi:https://doi.org/10.1016/j.Iwt.2017.01.029

Che, F., Sarantopoulos, I., Tsoutsos, T., and Gekas, V. (2012). Exploring a promising feedstock for biodiesel production in Mediterranean countries: A study on free fatty acid esterification of olive pomace oil. Biomass and Bioenerg, 36, 427-431. doi:https://doi. org/10.1016/j.biombioe.2011.10.005
Chiplunkar, P. P., and Pratap, A. P. (2016). Utilization of sunflower acid oil for synthesis of alkyd resin. Prog Org Coat, 93, 61-67. doi:https:// doi.org/10.1016/j.porgcoat.2016.01.002

Costa, J. F., Almeida, M. F., Alvim-Ferraz, M. C. M., and Dias, J. M. (2013). Biodiesel production using oil from fish canning industry wastes. Energ Convers Manage, 74, 17-23. doi:https://doi.org/10.1016/j. enconman.2013.04.032

Cruz, M., Pinho, S. C., Mota, R., Almeida, M. F., and Dias, J. M. (2017) Enzymatic esterification of acid oil from soapstocks obtained in vegetable oil refining: Effect of enzyme concentration. Renew Energ. doi:https://doi.org/10.1016/j. renene.2017.06.053

Dias, J. M., Alvim-Ferraz, M. C. M., and Almeida, M. F. (2009). Production of biodiesel from acid waste lard. Bioresource Technol, 100(24), 6355-6361. doi:https://doi.org/10.1016/j.biortech.2009.07.025

Echim, C., Verhe, R., Greyt, W. D., and Stevens, C. (2009). Production of biodiesel from side-stream refining products. Energy Environ Sci, 2, 1131-1141. doi:10.1039/B905925C

Foresti, M. L., Pedernera, M., Bucalá, V., and Ferreira, M. L. (2007). Multiple effects of water on solvent-free enzymatic esterifications. Enzyme Microb Tech, 41(1), 62-70. doi:https://doi.org/10.1016/j. enzmictec.2006.11.023

Go, A. W., Sutanto, S., Ong, L. K., Tran-Nguyen, P. L., Ismadji, S., and Ju, Y.-H. (2016). Developments in in-situ (trans) esterification for biodiesel production: A critical review. Renewable and Sustainable Energy Reviews, 60, 284-305. doi:https://doi.org/10.1016/j. rser.2016.01.070

Göğüş, F., and Maskan, M. (2006). Air drying characteristics of solid waste (pomace) of olive oil processing. J Food Eng, 72(4), 378382. doi:https://doi.org/10.1016/j.jfoodeng.2004.12.018

Haas, M. J. (2005). Improving the economics of biodiesel production through the use of low value lipids as feedstocks: vegetable oil soapstock. Fuel Process Technol, 86(10), 1087-1096. doi:https:// doi.org/10.1016/j.fuproc.2004.11.004

INE. (2018). Insituto Nacional de Estatistica - Statistic from Portugal. Retrieved from https://ine.pt/xportal/xmain?xpid=INEandxpgid=ine_indicadoresanduserLoadSave=LoadanduserTableOrder $=9286$ andtipoSeleccao $=1$ andcontexto=pqand selTab=tab1 andsubmitLoad=trueandxlang=pt

Irandoust, H., Samie, A. H., Rahmani, H. R., Edriss, M. A., and Mateos, G. G. (2012). Influence of source of fat and supplementation of the diet with vitamin $\mathrm{E}$ and $\mathrm{C}$ on performance and egg quality of laying hens from forty four to fifty six weeks of age. Anim Feed Sci Tech, 177(1), 75-85. doi:https://doi.org/10.1016/j.anifeedsci.2012.06.004

Kabbashi, N. A., Mohammed, N. I., Alam, M. Z., and Mirghani, M. E. S. (2015). Hydrolysis of Jatropha curcas oil for biodiesel synthesis using immobilized Candida cylindracea lipase. J Mol Catal B-Enzym, 116(Supplement C), 95-100. doi:https://doi.org/10.1016/j. molcatb.2015.03.009

Knothe, G., and Razon, L. F. (2017). Biodiesel fuels. Prog Energ Combust, 58, 36-59. doi:https://doi.org/10.1016/j.pecs.2016.08.001

López, I., Quintana, C. E., Ruiz, J. J., Cruz-Peragón, F., and Dorado, M. P. (2014). Effect of the use of olive-pomace oil biodiesel/diesel fuel blends in a compression ignition engine: Preliminary exergy analysis. Energ Convers Manage, 85, 227-233. doi:https://doi. org/10.1016/j.enconman.2014.05.084

Machado, G. D., de Souza, T. L., Aranda, D. A. G., Pessoa, F. L. P., Castier, M., Cabral, V. F., and Cardozo-Filho, L. (2016). Computer simulation of biodiesel production by hydro-esterification. Chem Eng Process, 103, 37-45. doi:https://doi.org/10.1016/j.cep.2015.10.015

Mahmudul, H. M., Hagos, F. Y., Mamat, R., Adam, A. A., Ishak, W. F. W., and Alenezi, R. (2017). Production, characterization and performance of biodiesel as an alternative fuel in diesel engines A review. Renew Sust Energ Rev, 72(Supplement C), 497-509. doi:https://doi.org/10.1016/j.rser.2017.01.001

Maurizio Servili, and Montedoro, G. (2002). Contribution of phenolic compounds to virgin olive oil quality. Eur J Lipid Sci Tech, 104, 302-613. doi:https://doi.org/10.1002/14389312(200210)104:9/10<602::AID-EJLT602>3.0.CO;2-X

Missaoui, A., Bostyn, S., Belandria, V., Cagnon, B., Sarh, B., and Gökalp, I. (2017). Hydrothermal carbonization of dried olive pomace: Energy potential and process performances. J Anal Appl Pyrol, 128, 281290. doi:https://doi.org/10.1016/j.jaap.2017.09.022

Orozco, M. I., Priego-Capote, F., and Luque de Castro, M. D. (2011). Influence of Deep Frying on the Unsaponifiable Fraction of Vegetable Edible Oils Enriched with Natural Antioxidants. Journal of Agricultural and Food Chemistry, 59(13), 7194-7202. doi:10.1021/ jf2015792 
Park, J.-Y., Kim, D.-K., Wang, Z.-M., Lee, J.-P., Park, S.-C., and Lee, J.-S. (2008). Production of biodiesel from soapstock using an ion-exchange resin catalyst. Korean J Chem Eng, 25(6), 1350-1354. doi:10.1007/s11814-008-0221-0

Pérez-Bonilla, A., Frikha, M., Mirzaie, S., García, J., and Mateos, G. G. (2011). Effects of the main cereal and type of fat of the diet on productive performance and egg quality of brown-egg laying hens from 22 to 54 weeks of age. Poultry Sci, 90(12), 2801-2810. doi:10.3382/ps.2011-01503

Piloto-Rodríguez, R., Melo, E. A., Goyos-Pérez, L., and Verhelst, S. (2014). Conversion of by-products from the vegetable oil industry into biodiesel and its use in internal combustion engines: a review. Braz J Chem Eng, 31(2), 287-301. doi:http://dx.doi.org/10.1590/0104$6632.20140312 \mathrm{~s} 00002763$

Rajaeifar, M. A., Akram, A., Ghobadian, B., Rafiee, S., Heijungs, R., and Tabatabaei, M. (2016). Environmental impact assessment of olive pomace oil biodiesel production and consumption: A comparative lifecycle assessment. Energy, 106, 87-102. doi:https://doi. org/10.1016/j.energy.2016.03.010

Rodrigues, R. C., and Ayub, M. A. Z. (2011). Effects of the combined use of Thermomyces lanuginosus and Rhizomucor miehei lipases for the transesterification and hydrolysis of soybean oil. Process Biochem, 46(3), 682-688. doi:https://doi.org/10.1016/j.procbio.2010.11.013

Sousa, J. S. d., Cavalcanti-Oliveira, E. d. A., Aranda, D. A. G., and Freire, D. M. G. (2010). Application of lipase from the physic nut (Jatropha curcas L.) to a new hybrid (enzyme/chemical) hydroesterification process for biodiesel production. J Mol Catal B-Enzym, 65(1), 133137. doi:https://doi.org/10.1016/j.molcatb.2010.01.003
Verdugo, C., Luna, D., Posadillo, A., Sancho, E. D., Rodríguez, S., Bautista, F., Romero, A. A. (2011). Production of a new second generation biodiesel with a low cost lipase derived from Thermomyces lanuginosus: Optimization by response surface methodology. Catal Today, 167(1), 107-112. doi:https://doi.org/10.1016/j.cattod.2010.12.028

Vescovi, V., Rojas, M. J., Baraldo, A., Jr., Botta, D. C., Santana, F. A. M., Costa, J. P., Tardioli, P. W. (2016). Lipase-Catalyzed Production of Biodiesel by Hydrolysis of Waste Cooking Oil Followed by Esterification of Free Fatty Acids. J Am Oil Chem Soc, 93(12), 1615-1624. doi:10.1007/s11746-016-2901-y

Watanabe, Y., Nagao, T., Nishida, Y., Takagi, Y., and Shimada, Y. (2007). Enzymatic Production of Fatty Acid Methyl Esters by Hydrolysis of Acid Oil Followed by Esterification. 84, 1015-1021. doi:10.1007/ s11746-007-1143-4

Zenevicz, M. C. P., Jacques, A., Furigo, A. F., Oliveira, J. V., and de Oliveira, D. (2016). Enzymatic hydrolysis of soybean and waste cooking oils under ultrasound system. Ind Crop Prod, 80, 235-241. doi:https://doi.org/10.1016/j.indcrop.2015.11.031

Živković, S. B., Veljković, M. V., Banković-llić, I. B., Krstić, I. M., Konstantinović, S. S., Ilić, S. B., Veljković, V. B. (2017). Technological, technical, economic, environmental, social, human health risk, toxicological and policy considerations of biodiesel production and use. Renew Sust Energ Rev, 79(Supplement C), 222-247. doi:https://doi. org/10.1016/j.rser.2017.05.048 